\title{
An acqueous extract of Bidens pilosa L. protects liver from cholestatic disease. Experimental study in young rats ${ }^{1}$
}

\author{
Um extrato aquoso de Bidens pilosa L. protege o fígado da doença colestática. Estudo \\ experimental em ratos jovens
}

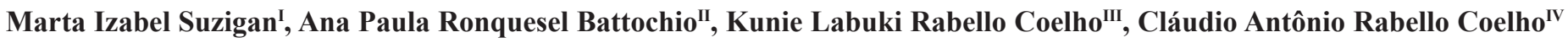 \\ ${ }^{\text {I }}$ Biologist, Department of Pediatrics, Botucatu School of Medicine, UNESP, Botucatu-SP, Brazil. \\ ${ }^{\text {II }} \mathrm{PhD}$ Biologist, Department of Pediatrics, Botucatu School of Medicine, UNESP, Botucatu-SP, Brazil. \\ III PhD, Assistant Professor, Head of the Division of Hepatic Histopathology, Department of Pathology, UNESP, Botucatu-SP, Brazil. \\ Iv $\mathrm{PhD}$, Assistant Professor, Head of the Division of Pediatric Hepatology, Department of Pediatrics, UNESP, Botucatu-SP, Brazil.
}

\begin{abstract}
Purpose: To test the hepatoprotective effect of water extract from Bidens Pilosa L. (BPE) in cholestatic liver disease induced by ligature and resection of the common bile ducts (LRBD) in young rats. Methods: We studied four groups of ten 21 days old (P21) Wistar rats, Group SW: sham operation and water; Group SD: sham operation and BPE (160 mg of fresh leaves/100 g of body weight/day); Group LW: LRBD and water and Group LD: LRBD and BPE daily. Pentobarbital sleeping time (PST) and serum activities of aspartate aminotransferase (AST) and of alanine aminotransferase (ALT) were determined after the sacrifice (P70). A Ruwart's score for hepatic fibrosis (RS) was given to each animal. Were employed two way ANOVA and the test of Tukey or a non-parametric test for multiple comparisons. Results: There were statistically significant differences between LW and LD in the measurements of the PST ((means $\mathrm{LW}=390 ; \mathrm{LD}=173$ ), AST (means $\mathrm{LW}=8, \mathrm{LD}=5$ ), ALT (medians $\mathrm{LW}=2 ; \mathrm{LD}=1$ ) e RS (medians $\mathrm{LW}=2$; $\mathrm{LD}=1$ ). Conclusion: $\mathrm{BPE}$ could be used in the phytotherapy of the hepatic damage induced by chronic obstructive cholestasis, because protects liver function, decreases the rate of necrosis and liver fibrosis in cholestatic liver disease.
\end{abstract}

Key words: Bidens. Phytotherapy. Cholestasis, Extrahepatic. Liver Cirrhosis, Biliary. Rats.

\section{RESUMO}

Objetivo: Testar o efeito hepatoprotetor do extrato aquoso de Bidens pilosa L. (EBP) na doença hepática induzida pela ligadura e ressecção do ducto biliar comum (LRDBC) em ratos jovens. Métodos: Estudamos ratos Wistar com 21․ dia de vida (P21) divididos em quatro grupos de 10 animais, Grupo SA: operação simulada e água; Grupo SD: operação simulada e EBP (160mg de folhas frescas/100g de peso corporal/dia); Grupo LA: LRDBC e água e Grupo LD: LRDBC e EBP diariamente. O tempo de sono por pentobarbital (TSP), aspartato (AST) e alanina (ALT) aminotransferase foram determinadas após o sacrifício (P70). O Score de Ruwart (SR) para fibrose hepática foi atribuído para cada animal. Foi realizada análise de variância com dois fatores e pelo teste de Tukey para comparações múltiplas ou por teste não paramétrico. Resultados: Houve diferença estatisticamente significativa entre LA e LD nas variáveis: TSP (médias LA=390; LD=173), AST (médias LA=8, LD=5), ALT (medianas LA=2; LD=1) e SR (medianas LA=2; LD=1). Conclusão: EBP poderá ser empregado na fitoterapia da doença hepática induzida pela colestase obstrutiva crônica, pois protege a função hepática, diminui a velocidade de necrose e a intensidade da fibrose hepática na obstrução biliar extra-hepática.

Descritores: Bidens. Fitoterapia. Colestase Extra-Hepática. Cirrose Hepática Biliar. Ratos.

${ }^{1}$ Research performed at the Infant Hepathology Division, Department of Pediatrics, School of Medicine of Botucatu, Sao Paulo State University (UNESP), Botucatu, Brazil.

\section{Introduction}

Considering its use in folk medicine in many countries (Brazil, China and Mexico) $)^{1,2,3}$ extracts of Bidens pilosa have been investigated and shown to have a choleretic effect in adult rats ${ }^{4}$ and to protect adult rat liver against toxic actions of $\mathrm{CCl}_{4}$ and acetaminophen ${ }^{2}$; the same effect has been shown using B. pilosa flavonoids ${ }^{5}$.
Our purpose was to test a possible hepatoprotective effect of a water extract of $B$. pilosa against cholestatic liver lesions caused by experimental ligature and resection of the common bile duct in young rats (P21- 21 days old). To test that effect, the degree of liver fibrosis, serum activities of aminotransferases and the pentobarbital sleeping time were measured. 


\section{Methods}

\section{Collection and preparation of water extract of Bidens pilosa (BPE)}

A sufficient amount of Bidens pilosa L was collected by one of us (Suzigan) in its natural occurrence, and authenticated by Dr. Airton Amaral Junior from the in Botanical Department of the Biosciences Institute, UNESP - São Paulo State University, Botucatu, who deposited one specimen in the Herbarium of his Department under the voucher number 22352. Leaves of Bidens pilosa were dried in an oven at $60^{\circ} \mathrm{C}$ for 72 hours, ground with pestle and mortar, and suspended in water in the proportion of 60 grams per one liter of water. The suspension was filtered through a paper filter and stored in aliquots of $100 \mathrm{ml}$ at minus $20^{\circ}$ Cesius, until use $100 \mathrm{~g}$ of wet leaves produced in average, $18.76 \mathrm{~g}$ of dried leaves.

\section{Experimental design}

The independent variables were: 1) the presence or absence of cholestasis (ligature and common bile duct resection or sham operation) and 2) the administration or not of $B$. pilosa extracts daily by gavage. Instead of BPE, water was given also by gavage in the same volume as the extract.

The dependent variables analyzed were: 1) serum aminotransferases activities; 2) pentobarbital sleeping time and 3) Ruwart's score for fibrosis.

\section{Animal care}

The use of laboratory animals followed the Council for International Organization of Medical Sciences (CIOMS) ethical code for animal experimentation ${ }^{6}$ and the principles of the Brazilian College on Animal Experimentation?

\section{Experimental procedure}

Forty male Wistar rats were used, born in the Pediatrics Experimental Laboratory, they were kept in controlled environmental conditions - a temperature of $22^{\circ}$ to $23^{\circ}$ Celsius and light/ dark cycle of 12 hours. From birth until P21, they were nursed in groups of six animals. Immediately after weaning they were divided into four groups of ten animals each.

The experiment with each animal was run from P21 up to P70. They were born from nulliparous females weighing between 180 and $220 \mathrm{~g}$ at mating, provided by the Animal Center of the Botucatu Campus - UNESP. From birth up to the beginning of the experiment, the animals were nursed in litters of 6 pups each, without access to the chow given to the mother and weaned at the beginning of the experiment.

During the experiment each animal was housed in an individual cage and received water and standard chow ad libitum. Environmental temperature was kept form $23^{\circ}$ to $24^{\circ}$ Celsius. A circadian cycle of lignt/shade of 12 hours was maintained.

\section{Experimental groups}

At P21, forty male Wistar rats were randomly allocated to one of the following four experimental groups:

Group SW: sham operation, under light ether anesthesia, and daily administration by gavage, of $0.5 \mathrm{ml}$ per 100 grams of body weight of water.

Group SD: sham operation plus daily administration, by gavage, $0.5 \mathrm{ml}$ per 100 grams of body weight of water extract of Bidens Pilosa (BPE). The dose corresponds to $160 \mathrm{mg}$ of fresh leaves $/ 100 \mathrm{~g}$ of body weight.

Group LW: double ligature and resection of the common bile duct - LRBD (for surgical technique, see below) plus daily administration by gavage, of water in the same volume as the volume of extract given to the experimental groups.

Group LD: double ligature and resection of the common bile duct plus daily administration by gavage of acqueous extract of bidens pilosa (BPE) in the same volume given to the experimental groups.

\section{Surgical technique}

Double ligature and common bile duct resection (LRBD), was performed according to the technique adapted by the UNESP Department of Pediatrics Hepatology Group ${ }^{8}$, from the technique described by Cameron and Oakley 9 . The bile duct and the hepatic artery were dissected one from the other, eliminating the possibility of ligating the artery and the duct together. The sham operation followed exactly the same procedure, excepting the double ligature and resection of the common bile duct. During surgery the animals received light ethylic ether anesthesia. After euthanasia (see below) the hepatic hilum area was inspected in order to rule out any collection of bile or dilatation of the proximal bile duct remnant. The cholestatic liver disease was confirmed by and histopathologic liver examination.

\section{Pentobarbital sleeping time (PST)}

On P69, the pentobarbital sleeping time test was performed using pentobarbital. The animals received pentobarbital (concentration of $3 \mathrm{~g} / 100 \mathrm{ml}$ of solution) through intraperitoneal injection at a dosage of $50 \mathrm{mg} / \mathrm{kg}$ of rat body weight (or $0.0017 \mathrm{ml} / \mathrm{g}$ of animal weight) and time was measured in minutes, from the loss of position reflex to its recuperation.

\section{Euthanasia}

Euthanasia was performed on P70, beginning with an intraperitoneal injection of sodium pentobarbital and exsanguinated through a cardiac puncture. The blood and liver were collected for biochemical tests.

\section{Biochemical studies}

Blood for determinations of activity of aminotransferases (aspartate aminotransferase - AST and alanine aminotransferase ALT) was drawn at the P70 the beginning of each experiment. For these determinations the UV kinetic method was employed, using reagents supplied by CELM. 


\section{Histopathological studies}

The animals were sacrificed at the P70 after the beginning of each experiment. Histological sections of a fragment taken from the right lobe of the liver were stained by the Masson's method; three sections from each animal were examined under light microscopy. A Ruwart's score for fibrosis was assigned to each animal. By one observer according to the following criteria: Score zero - Normal or slightly increased collagen; score one - collagen increased, with no septa but with stellate expansions of the portal tract or pericellular fibrosis; score two - incomplete septa; score three - thin septa; score four - thick septa.

\section{Statistical procedures}

The means, medians and standard deviations of the resulting data for each variable in each group and were calculated.

Tests for normality and for equality of variances were applied to the data of each variable. If the variable passed both tests, a two-way ANOVA was applied, being the factors -1) surgical manipulation (ligature and resection of the common bile or sham operation) in two levels - presence of cholestasis and absence of cholestasis), and 2) administration of BPE in two levels - administration of the extract and administration of water.

If the test showed a significant interaction between the two factors the Tukey test for multiple comparisons was applied on four pairs of groups (LW and LD; SW and SD; LW and SW, LD and SD). This was the case with the PST and AST.

If the variable did not pass one or both tests for normality and equality of variances, different mathematical transformations were tried until the data passed the tests. The natural logarithms of the ALT values were substituted for its raw values and a two-way ANOVA test and Tukey test were applied as mentioned above.

If after the mathematical transformations, the data still did not pass the tests for normality and equality of variances, a Kruskall-Wallis Anova on ranks was performed. If this test showed a significant difference between the groups, the StudentNewman-Keuls (S.N.K) test was applied on four pairs of groups (LW and LD; SW and SD; LW and SW; $\mathrm{LD}$ and SD); if the probability of an $\alpha$ error was less than 0.01, it was concluded that the medians of the groups were statistically different one from the other This was the case with the Ruwart's Score for fibrosis.

\section{Results \\ Pentobarbital sleeping time}

There was a significant interaction $(p \leq 0.001)$ between the effects of the use of BPE and of the on the PST, and a significant difference (Tukey test: $\mathrm{p}<0.05)$ between the means of LW (390.0 min) and LD (173.6 min) (Table 1 and Figure 1).

\section{Biochemical studies}

There was a significant interaction $(\mathrm{p}=0.011)$ between the effects of the use of BPE and of the cholestasis on the AST and a significant difference (Tukey test: $p<0.05$ ) between the means of LW (8 IU/1) and LD (5 IU/1) (Table 1 and Figure 1).

There was no significant interaction between the effects of the use of BPE and of the cholestasis on the ALT ( $\mathrm{p} \geq 0.05)$, but there was an effect of cholestasis independently of the effect of the BPE (LW and SW) and the multiple comparisons showed a significant difference (Tukey test: $p<0.05$ ) between LW $($ median $=3.52)$ and LD $($ median $=2.19)($ Table 1 and Figure 1$)$.

\section{Histopathological studies}

There was a statistically significant difference among the medians for the Ruwart's score of the four groups. The multiple paired comparisons by the S.N.K. $(p \leq 0.001)$ showed an effect of cholestasis on fibrosis in both cholestatic groups, treated or non treated with BPE (LW versus SW and LD versus SD) and between the medians of LW $($ median $=2)$ and LD $($ median $=1)$ (Table 1 and Figure 1), suggesting an anti-fibrotic effect of BPE.

TABLE 1 - Pentobarbital sleeping time, aminotransferase serum activities (ALT and AST) and Ruwart's score - descriptive analysis, interaction and comparisons between effects of cholestasis and of BEP

\begin{tabular}{|c|c|c|c|}
\hline Variables & Descriptive statistics ${ }^{A}$ & Interaction $^{B}$ & Comparison $^{c}$ \\
\hline $\begin{array}{l}\text { Pentobarbital } \\
\text { Sleeping } \\
\text { Time } \\
\text { (min.) }\end{array}$ & $\begin{array}{l}\text { Mean } \pm \text { SD } \\
\text { SW=98.40 } \pm 21.20 \\
S D=117.70 \pm 32.48 \\
L W=390.00 \pm 5.8 \\
\text { LD }=173.60 \pm 58.67\end{array}$ & $\begin{array}{c}\mathrm{p} \leq 0.001 \\
\text { Significant }\end{array}$ & $\begin{array}{c}L W>L D p<0.05 \mathrm{~s} . \\
L W>S W p<0.05 \mathrm{~s} \\
L D>S D p<0.05 \mathrm{~s} . \\
S W \approx S D p=0.675 \text { n.s. }\end{array}$ \\
\hline AST (IU/L) & $\begin{array}{l}\text { Means } \pm \text { SD } \\
\text { SW }=4.16 \pm 0.76 \\
\text { SD }=4.06 \pm 0.37 \\
\mathrm{LW}=8.03 \pm 0.77 \\
\mathrm{LD}=5.03 \pm 0.40\end{array}$ & $\begin{array}{c}p=0.011 \\
\text { Significant }\end{array}$ & $\begin{array}{l}L W>L D p<0.05 \text { s. } \\
L W>S W p<0.05 \text { s. } \\
L D \approx S D p<0.083 \text { n.s. } \\
S W \approx S D p=0.882 \text { n.s. }\end{array}$ \\
\hline InALT & $\begin{array}{l}\text { Medians } \\
\text { SW=2.12 } \\
S D=1.70 \\
L W=3.52 \\
L D=2.19\end{array}$ & $\begin{array}{c}p=0.041 \\
\text { Significant }\end{array}$ & $\begin{array}{l}L W>L D p<0.05 \text { s. } \\
L W>S W p<0.05 \text { s. } \\
L D \approx S D p=0.639 \text { n.s. } \\
S W \approx S D p=0.155 \text { n.s. }\end{array}$ \\
\hline Ruwart's score & $\begin{array}{l}\text { Medians } \\
\text { SW }=0 \\
S D=0 \\
L W=2.00 \\
L D=1.00\end{array}$ & $\begin{array}{c}p \leq 0.001 \\
\text { Significant }\end{array}$ & $\begin{array}{l}L W>L D p<0.05 s . \\
L W>S W p<0.05 s . \\
L D \approx S D p<0.05 s . \\
S W \approx S D p=1,000 \text { n.s. }\end{array}$ \\
\hline
\end{tabular}

$\mathbf{A}=$ Descriptive analysis; $\mathbf{S D}=$ Standard deviation; $\mathbf{B}=$ Interaction; $\mathbf{C}=$ multiple paired comparisons using the Tukey Test or S.N.K; $\mathbf{s}=$ significant; n.s. = non-significant; $\mathbf{S W}=$ sham operation with administration of water; $\mathbf{S D}=$ sham operation with administration of BEP; $\mathbf{L W}=$ double ligature with common bile duct resection with administration of water; $\mathbf{L D}=$ double ligature with common bile duct resection with administration of BEP; min. =minutes; IU/L = International Units per Liter. 


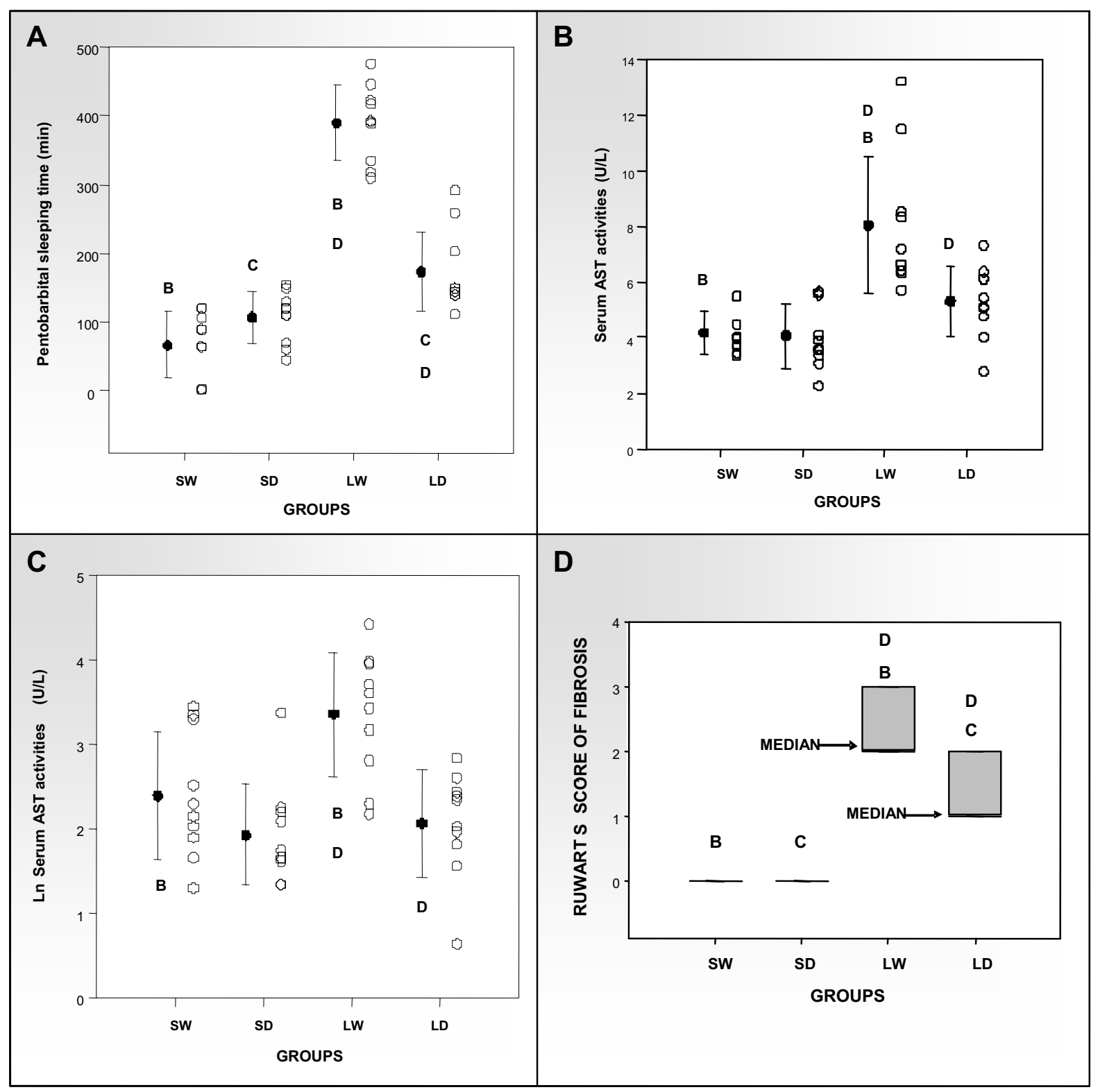

FIGURE 1 - Means, standard deviations and individual values of: (A) pentobarbital sleeping time (min.); (B) aminotransferase serum activity AST (IU/L); (C) aminotransferase serum activity ALT (IU/L); (D) Ruwart's score for fibrosis in rats in groups of 10, submitted to one of the following treatments: SW: sham operation with daily administration of water; SD: sham operation with daily administration of BEP; $\mathbf{L W}$ : double ligature with common bile duct resection with daily administration of water; LD: double ligature with common bile duct resection with daily administration of BEP. Letters repeated indicate the paired groups with significant differences ( $\mathrm{p}<0.05)$ : between them in the Tukey Test (A,B,C) or in the $\mathrm{SNK}$ test (D). A=SW $>\mathrm{SD}$; $\mathbf{B}=\mathrm{LW}>\mathrm{SW} ; \mathbf{C}=\mathrm{LD}>\mathrm{SD} ; \mathbf{D}=\mathrm{LW}>\mathrm{LD}$.

\section{Discussion}

There is no published study on the effect of B. Pilosa extracts either on adult or young rats with this model of chronic obstructive cholestasis.

There are studies on the hepatoprotective effect in adult rats of the extract against toxic experimental liver lesion $-\mathrm{CCl}_{4}$ and acetaminophen. There are also studies showing this hepatoprotective effect of $B$. pilosa flavonoids against the same toxic substances.

Our group has studied on the same model the hepatoprotective effect of another plant extract (Coleus barbatus ${ }^{10}$ also called C. forskohlii).

There are no published hepatoprotective effect of $B$. pilosa extract neither in young rats nor with chronic obstructive extra-hepatic cholestasis.

Cholestatic liver damage in young rats caused an increase in AST activity of the cholestatic group that did not receive $B$. pilosa extract (LW), was increased when compared with that of the LD, and in ALT activity of the cholestatic group that did not receive $B$. pilosa extract was increased when compared with that of the sham operated group and of AST.

The same has been observed in other similar experiments with cholestatic liver damage in rats - alpha-naphthylisothiocyanateinduced liver injury ${ }^{11,12}$; parenteral nutrition-associated cholestasis ${ }^{13}$; 
bile duct ligation ${ }^{14,15,16}$; cyclosporine induced hepatotoxicity in the isolated perfused rat liver ${ }^{17}$; falloidin-induced transient cholestasis $^{18}$. Also in models of hepatocyte damage In conclusion, TFB was able to ameliorate liver injury and protect rats from $\mathrm{CCl}_{4}-$ induced liver fibrosis by suppressing oxidative stress. This process may be related to inhibiting the induction of NF-kappaB on hepatic stellate cell activation and the expression of TGF-beta1. In mice, with $\mathrm{CCl}_{4}$-induced liver disease ${ }^{5}$, oral administration of TFB significantly reduced the elevated relative values of liver weight, serum transaminases (alanine aminotransferase and aspartate aminotransferase) and the hepatic morphologic changes and markedly inhibited $\mathrm{CCl}_{4}$-induced lipid peroxidation and enhanced the activity of the antioxidant enzymes superoxide dismutase and glutathione peroxidase. Moreover, pretreatment with TFB suppressed nitric oxide production and nuclear factor-kappaB activation in $\mathrm{CCl}_{4}$-treated mice.

At doses of 50, 100 and $200 \mathrm{mg} \mathrm{kg}(-1)$ for 7 days The results suggest that TFB has significant hepatoprotective activity and its mechanism is related, at least in part, to its antioxidant properties induced by $\mathrm{CCl}_{4}$ in mice in addition 5 .

Fujii ${ }^{19}$ summarized the toxicological correlation between blood biochemical parameters and liver histopathological findings in rats and dogs on the basis of his experiments and published papers and concluded that ALT and AST increased with a good correlation to necrotic severity.

We observed a significant decrease in the mean of ASP in cholestatic rats receiving BPE (47.84 IU/L) as compared with those that did not received it (136.67 IU/L) and the same was observed in the medians of ALT in cholestatic animals (34.03 IU/L) and in cholestatic animals receiving BPE $(9.04 \mathrm{IU} / \mathrm{L})$. A decrease in the activity of these enzymes has been used as an indicative of therapeutic or preventive effect in many experimental models of liver damage, including cholestatic liver damage in rats ${ }^{13}$ used it to study the effects of acetylsalicylic acid, interferon-alpha, and vitamin $\mathrm{E}$ on prevention of parenteral nutrition-associated cholestasis; Muriel et al. ${ }^{20}$ in a model of acute cholestasis in the rat to demonstrate that it is ameliorated partially by L-arginine; Benz et al. ${ }^{21}$ to study the effect of tauroursodeoxycholic acid on bile-acid-induced apoptosis and cytolysis in rat hepatocytes; Muriel $^{22}$ to demonstrate the protective effect of a low fat diet on cholestatic liver damage after biliary obstruction.

Cholestatic liver damage in young rats caused an increase in PST - the median (390 min) of the LW was significantly higher than that of the LD (98 min). The PST has been used as a simple and non-invasive test of liver function ${ }^{23}$. Its lenght is related to the rate of desintoxication of pentobarbital by the P-450 cytochroms in the liver ${ }^{24}$. The hepatocytic damage of the cholestasis induced by the ligature of the bile duct lowers the isoenzymes of the P-450 cytochromes $^{25}$. Ursodeoxycholic acid prevents hepatic cytochrome $\mathrm{P}-450$ isozyme reduction in rats with deoxycholic acid-induced liver injury ${ }^{26}$. A decrease in pentobarbital sleeping time has been used as a criterium for preventive or therapeutic effects in many experimental models of liver damage and cholestasis ${ }^{27,28,29,30,31,32,33,34,35,36}$.

Biliary obstruction has been used as a model of cholestatic liver damage resulting in fibrosis, and secondary biliary cirrhosis in rats ${ }^{37,14,38,39,40}$. The median (2.0) of the Ruwart's score for fibrosis of the cholestatic group that did not receive $B$. pilosa extract was significantly increased when compared with that of the control group SW (0.0). A decrease in the intensity of liver fibrosis has been used as an indicative of therapeutic effect in many experimental models of liver damage and of cholestasis ${ }^{41}$ to study a possible protective effects of lipoic acid. The treatment with BPE did significantly reduced the fibrosis in cholestatic rats (the median of the Ruwart's score for fibrosis was 1.0 in this group).

In summary, the BPE protected against the hepatocyte damage and the liver fibrosis in this model of cholestatic liver damage and fibrosis. It might be a non - specific effect, since BPE also protect the hepatocyte in $\mathrm{CCl}_{4}$ liver damage ${ }^{2}$, but it might also have a specific effect, protecting against the detergent action of retained bile salts and /or againt the cholestasis induced by mono hydroxylated bile acids. From the many known components of $B$. pilosa the flavonoids could be the active principle, since some of them as silymarin ${ }^{42}$ and diosmin protect against the membrane damage induced by the cholestatic agent, erythromycin estolate ${ }^{43}$. Further research is needed to identify the active substance and its mode of action.

\section{Conclusion}

The acqueous extract of Bidens pilosa L. protects the liver against damage induced by chronic obstructive cholestasis in young rats and therefore should be considered in the treatment of analogous disease in children.

\section{References}

1. Kviecinski MR, Felipe KB, Schoenfelder T, de Lemos Wiese LP, Rossi MH, Gonçalez E, Felicio JD, Filho DW, Pedrosa RC. Study of the antitumor potential of Bidens pilosa (Asteraceae) used in Brazilian folk medicine. J Ethnopharmacol. 2008;117(1):69-75.

2. Chih HW, Lin CC, Tang KS. The hepatoprotective effects of Taiwan folk medicine ham-hong-chho in rats. Am J Chin Med.1996;24:231-40.

3. Astudillo-Vázquez A, Dávalos Valle H, De Jesús L, Herrera G, Navarrete A. Investigation of Alternanthera repens and Bidens odorata on gastrointestinal disease. Fitoterapia. 2008;79(7-8):577-80.

4. Yomura MH; CURI PR; JESUS MAL; COELHO CAR. Efeitos da suspensão aquosa de folhas secas do picão (Bidens pilora $\mathrm{L}$ ) sobre o fluxo biliar em ratos. Arq Bras Med. 1988;62(4):281-2.

5. Yuan LP, Chen FH, Ling L, Dou PF, Bo H, Zhong MM, Xia LJ. Protective effects of total flavonoids of Bidens pilosa L. (TFB) on animal liver injury and liver fibrosis. J Ethnopharmacol. 2008;116(3):539-46.

6. Howard-Jones N. A. CIOMS ethical code for animal experimentation. WHO Chron. 1985;39(2):51-6.

7. Comissão de Ensino do Colégio Brasileiro de Experimentação Animal (COBEA). Manual para técnica em bioterismo; 1996. Disponível em URL: http://www.cobea.org.br

8. Battochio APR, Santos AG, Silva CRM, Santos AR, Coelho CAR. Adaptação do modelo experimental de colestase extra-hepática em ratos jovens. Acta Cir Bras. 2004;19(1):70-3.

9. Cameron GR, Oakley CL. Ligation of the common bile duct. J Pathol Bacteriol. 1932;35:769-99.

10. Battochio AP, Coelho KL, Sartori MS, Coelho CA. Hepatoprotective effect of water soluble extract of Coleus barbatus on cholestasis on young rats. Acta Cir Bras. 2008;23(3):220-9.

11. Kongo M, Ohta Y, Nishida K, Sasaki E, Harada N, Ishiguro I. An association between lipid peroxidation and alpha-naphthylisothiocyanateinduced liver injury in rats. Toxicol Lett. 1999;105:103-10.

12. Neghab M, Stacey NH. Alpha-naphthylisothiocyanate-induced elevation of serum bile acids: lack of causative effect on bile acid transport. Chem Biol Interact.1996;99:179-92. 
13. Demircan M, Ugaralp S, Mutus M, Gurer EI, Atik E, Turhan F, Gursoy $\mathrm{MH}$. The effects of acetylsalicylic acid, interferon-alpha, and vitamin $\mathrm{E}$ on prevention of parenteral nutrition-associated cholestasis: an experimental study. J Pediatr Gastroenterol Nutr. 1999;28:291-5.

14. Parola M, Leonarduzzi G, Robino G, Albano E, Poli G, Dianzani UM. On the role of lipid peroxidation in the pathogenesis of liver damage induced by long-standing cholestasis. Free Radic Biol Med. 1996;20:351-9. 15. Lechner AJ, Velasquez A, Knudsen KR, Johanns CA, Tracy TF Jr, Matuschak GM. Cholestatic liver injury increases circulating TNF-alpha and IL-6 and mortality after Escherichia coli endotoxemia. Am J Respir Crit Care Med. 1998;157:1550-8.

16. Olynyk JK, Yeoh GC, Ramm GA, Clarke SL, Hall PM, Britton RS, Bacon BR, Tracy TF. Gadolinium chloride suppresses hepatic oval cell proliferation in rats with biliary obstruction. Am J Pathol. 1998;152;347-52. 17. Deters M. Strubelt Younes M. Reevaluation of cyclosporine induced hepatotoxicity in the isolated perfused rat liver. Toxicology. 1997;123:197-206. 18. Loranger A, Barriault C, Yousef IM, Tuchweber B. Structural and functional alterations of hepatocytes during transient phalloidin-induced cholestasis in the rat. Toxicol Appl Pharmacol. 1996;137:100-11.

19. Fujii T. Toxicological correlation between changes in blood biochemical parameters and liver histopathological findings. J Toxicol Sci. 1997;22:161-83. 20. Muriel P, González P. Liver damage induced by acute cholestasis in the rat is ameliorated partially by L-arginine. Comp Biochem Physiol C Pharmacol Toxicol Endocrinol. 1998;120(3):421-4.

21. Benz C, Angermuller S, Tox U, Kloters-Plachky P, Riedel HD, Sauer P, Stremmel W, Stiehl A. Effect of tauroursodeoxycholic acid on bileacid-induced apoptosis and cytolysis in rat hepatocytes. J Hepatol. 1998;28:99-106.

22. Muriel P. High fat diet and liver damage induced by biliary obstruction in the rat. J Appl Toxicol. 1995;15:125-8.

23. Lutz J, Wagner M. Recovery from pentobarbital-induced sleep after administration of perfluorinated blood substitutes. Artif Organs. 1984;8:41-3. 24. Lutz J, Krafft MP. Longitudinal studies on the interaction of perfluorochemicals with liver cytochromes P-450 by means of testing the rate of detoxification of pentobarbital. Adv Exp Med Biol. 1997;411:391-4. 25. Tateishi T, Watanabe M, Nakura H, Tanaka M, Kumai T, Kobayashi S. Liver damage induced by bile duct ligation affects CYP isoenzymes differently in rats Pharmacol Toxicol. 1998;82:89-92.

26. Tanaka M, Nakura H, Tateishi T, Watanabe M, Nakaya S, Kumai T, Kobayashi S Ursodeoxycholic acid prevents hepatic cytochrome P450 isozyme reduction in rats with deoxycholic acid-induced liver injury. J Hepatol. 1999;31(2):263-70.

27. Gilani AH, Janbaz KH, Shah BH. Esculetin prevents liver damage induced by paracetamol and CCl4. Pharmacol Res. 1998;37:31-5.
28. Gilani AH, Janbaz KH, Shah BH. Quercetin exhibits hepatoprotective activity in rats. Biochem Soc Trans. 1997;25(4):S619.

29. Gilani AH, Janbaz KH. Studies on protective of Cyperus scariosus extract on acetaminiphen and $\mathrm{CCl} 4$ - induced hepatotoxicity. Gen Pharmacol. 1995;26:627-31.

30. Janbaz KH, Gilani AH. Evaluation of the protective potential of Artemisia maritima extract on acetaminophen- and CCl4-induced liver damage. J Ethnopharmacol. 1995:47:43-7.

31. Gilani AH, Janbaz KH. Hepatoprotective effects of Artemisia acoparia against carbon tetrachloride: an environmental contaminant. J Park Med Assoc. 1994;44:65-8.

32. Van Puyvelde L, Kayonga A, Brioen P, Costa J, Ndimubakunzi A, De Kimpe N, Schamp N The hepatoprotective principle of Hypoestes triflora leaves. J Ethnopharmacol. 1989;26(2):121-7.

33. Wang Y, Lei HP. Hepatotoxicity of gossypol in rats. J Ethnopharmacol. 1987;20:53-64.

34. Kusek JC. Lidocaine metabolism and toxicity: a laboratory experiment for dental students. J Dental Educ. 1980;44:218-20.

35. Davis ME, Mehendale HM. Functional and biochemical correlates of chlordecone exposure and its enhancement of CCl4 hepatotoxicity. Toxicology. 1980;15:91-103.

36. Weisburger JH, Schmehl EA, Pai SR. Liver damage by the carcinogen N-hydroxy-N-2-fluorenylacetamide. Pentobarbital sleeping time and liver morphology. Toxicol Appl Pharmacol. 1965;7:579-87.

37. Wasser S, Tan CE. Experimental models of hepatic fibrosis in the rat. Ann Acad Med Singapore. 1999;28:109-11.

38. Gadano AC, Sogni P, Heller J, Moreau R, Bories PN, Lebrec D. Vascular nitric oxide production during the development of two experimental models of portal hypertension. J Hepatol. 1999;30:896-903.

39. Tuchweber B, Desmouliere A, Costa M, Yousef IM, Gabbiani G. Myofibroblastic differentiation and extracellular matrix deposition in early stages of cholestatic fibrosis in rat liver. Curr Top Pathol. 1999;93:103-9. 40. Park EJ, Ko G, Kim J, Sohn DH. Biotransformation of theophylline in cirrhotic rats induced by biliary obstruction. Arch Pharm Res. 1999;22:60-6. 41. Marley R, Holt S, Fernando B, Harry D, Anand R, Goodier D, Davies $\mathrm{S}$, Moore K. Lipoic acid prevents development of the hyperdynamic circulation in anesthetized rats with biliary cirrhosis. Hepatology. 1999;29:1358-63.

42. Miguez MP, Anundi I, Sainz-Pardo LA, Lindros KO. Hepatoprotective mechanism of silymarin: no evidence for involvement of cytochrome P450 2E1. Chem Biol Interact. 1994;91:51-63.

43. Villa P, Cova D, De Francesco L, Guaitani A, Palladini G, Perego R. Protective effect of diosmetin on in vitro cell membrane damage and oxidative stress in cultured rat hepatocytes. Toxicology. 1992;73:179-89.

\section{Correspondence:}

Conflict of interest: none

Ana Paula Ronquesel Battochio

Av. Bento Lopes, 110

18618-000 Botucatu - SP Brazil

Phone: (55 14)9123-9276

Fax: (55 14)3811-6274

apbattochio@,ig.com.br

Received: March 11, 2009

Review: May 14, 2009

Accepted: June 17, 2009

\section{How to cite this article}

Suzigan MI, Battochio APR, Coelho KLR, Coelho CAR. An acqueous extract of Bidens pilosa L. protects liver from cholestatic disease. Experimental study in young rats. Acta Cir Bras. [serial on the Internet] 2009 Sept-Oct;24(5). Available from URL: $\underline{\text { http://www.scielo.br/acb }}$ 